\title{
W. B. Yeats and the Quest for Order
}

\author{
Hamdi Hamdeed Al-Douri ${ }^{1}$ \\ ${ }^{1}$ Department of English, College of Education for Women, Tikrit University, Tikrit, Iraq
}

\begin{abstract}
This paper is an attempt to explore Yeats's quest for order and how this quest found expression in his works. Throughout his life, Yeats was dissatisfied with the religious, artistic, political, anthropological and intellectual aspects of life, in both Ireland and England which have taken away from modern man the sense of order. His father's skepticism, his dissatisfaction with the spiritless religion of his time, a religion which seems dead and his sense of alienation at school among British students were behind his ceaseless search for alternative orders which became the preoccupation of all his life and triggered his [] engagements in numerous nationalistic, occult, and mystical societies which he joined early in his life. Among the societies he joined was the Balvatsky Lodge of the Russian Lady Madam Balvatsky through which he came into close contact with the occult. One of the most important societies he joined and presided was the occult society the Golden Dawn. This paper, therefore, sheds light on his quest for nationalist, intellectual, philosophical, and mystical orders and how this is reflected in his poetry. The paper attempts to explore this quest for order selected poems such as "The Lake Isle of Innisfree", "The Second Coming", "Leda and the Swan", "Sailing to Byzantium" and some other poems together with reference to his philosophical book A Vision. However, the dominating quest in Yeats's poetry is his quest for a mystical order which can be traced in almost all his poetical works.
\end{abstract}

KEY WORDS: Mysticism, Order, Poetry, Quest, Yeats.

\section{YEATS'S QUEST FOR ORDER}

Yeats's quest for order started at an early phase in his life due to many influences. The first influence on Yeats came from his father J. W. Yeats, the artist, who encouraged him to write and who listened to Yeats reading aloud his own favorite poems. However, J. B. Yeats was a "forceful skeptic," therefore, his son "hurled himself headlong into the pursuit of the truth" trying to find "a substitute for religion, searching for a language of symbols" (Jeffares, 1979, p. 7). He, therefore, begins

Koya University Journal of Humanities and Social Sciences (KUJHSS),

Volume 3, Issue 1, 2020.

Received 31 May, 2019; Accepted 21 June, 2019,

Regular research paper: Published 18 June 2020

Corresponding author's e-mail: hyousif@tu.edu.iq

Copyright (C2020 Hamdi H. Al-Douri. This is an open access article distributed under the Creative Commons Attribution License.
The Trembling of the Veil describing his effort to make what he calls a new religion:

I was unlike others of my generation in one thing only, I am very religious, and deprived of Huxley [Thomas Huxley18251895] and Tyndal [William Tindal 1492-1536], whom I detested, of the simple-minded religion of my childhood. I had made a new religion, almost an infallible church of poetic tradition, of a fardel of stories, and of personages, and of emotions, inseparable from their first expression, passed on from generation to generation by poets and painters with some help from philosophers and theologians (Yeats, 1966, p. 115).

The impact of science on the minds of the last Victorians and the early 20th-century poets and writers was also so great that any study of the literature of the period should take it into consideration. "The cause," maintains Theodore Spencer, "is fairly obvious, Science and particularly anthropological science has taken away from man the sense of order" (Spencer, p. 90). The literature produced from about 1880 to 1914, to use John Burgess Wilson's words "is characterized either by an attempt to find substitutes for a religion which seems 
dead, or by a kind of spiritual emptiness - a sense of helplessness of trying to believe in anything" (Wilson, p. 269).

Some, therefore, found their substitute in humanism; some in pessimism; some in escapism, stoicism, or in art (Strandberg, p. 481-482). Yeats's response, especially in his early career, was an escapist one. This escapist attitude was behind his ceaseless search for a substitute belief and behind his quest for order. Yeats's early interest in contemporary science in his teens was soon alienated by the "Ordic Force which he discovered in Sinnett's Esoteric Buddhism" that he became an esoteric Buddhist to agree with William Blake- "and incidentally with Nietzsche - that science is the tree of death" and to believe that true religion is "something revealed to theosophists and also poets." He proposed to the Hermetic Society in Dublin that the poets' mythology and "their spirits of water and wind were literal truths" and that we could come to the nearest to an authoritative religion in what the "great poets had affirmed in their finest moments" (MacNeice, p. 58-59).

His father's unbelief, Yeats admits, was one of the reasons behind his search for a system: "My father's unbelief had set me thinking about the evidence of religion and I weighed the matter perpetually with great anxiety, for I did not think I could live without religion" (Qtd. in Unterecker, 1971, p. 19). Art, he thought, would not do because it would be of little value if it did not represent an order greater than itself (ibid 19). Hence, Yeats was obsessed at an early age with the idea of an external order. "The chief difficulty facing the modern poet," argues Spencer, is "that he no longer shares a common background which can give him an ordered emotional symbolism" (Spencer, p. 90-91). As far as Yeats is concerned, Spencer adds.

No one has been more aware of the contemporary problem than Mr. Yeats; the question of an external order, and the individual's relation to it has been his constant preoccupation. In his earliest poems he sought "some symbolic language reaching far back into the past and associated with familiar names and conspicuous hills that I might not be alone amid the obscure impressions of the senses;" and in the poems of his second period he strove to express "those simple emotions which resemble the more, the more powerful they are, everybody's emotions.... I was soon to write many poems where an always personal emotion was woven into a general pattern of myth and symbol" (Spencer, p. 91). Yeats's ceaseless quest for order is evident from the numerous movements and societies he joined in his early career. His quest for order, according to Richard Ellmann takes three directions: "In a form of literature, in a form of philosophy, and a belief in nationality (Ellmann, p. 42). However, Ellmann does not mention Yeats's quest for a spiritual or mystical order which was the obsession of all his life and which does not exactly belong to the philosophical order.

Yeats nationalistic interest started under the influence of John O'Leary who introduced him to the movement of Young Ireland and later to Maude Gonne (the love of his life). Under O'Leary's influence "he dreamed of bringing the two halves of Ireland, Catholic, and Protestant," and he decided that for himself personal utterance in poetry depended on his Irish background (MacNeice, p. 59). He even joined the secret extremist revolutionary Irish Republican Brotherhood for a time (Jeffares, 1974, pp. xii-xiv). However, Yeats first contact with the active Irish nationalists was probably through Charles Hubert Oldham, who was chiefly responsible in 1885 for founding the Dublin University Review, in which Yeats published his poems (Ellmann, p. 45). Yeats major concern was to create specifically Irish literature derived from the Irish folk fairy tales and the Gaelic legends, the Cuchulain saga, and the tales of Fianna, which he read in 19th-century translations. Through such a kind of literature, the "Unity of Culture" can be achieved.

Yeats sense of alienation from British culture became acute when his family moved to London, and he attended the Godolphin School in Hammersmith. At Godolphin School his nationalistic feeling was aroused for the 1st time when he was persecuted by other boys for being Irish (Ronsley, p. 47). Yeats sought unity in Ireland as a whole. He sought unity first among individuals, then in the nation as a whole. He suggested that this can be attained through art; his interest in art and Irish nationalism was brought together. By discovering an uninhabited island castle in Lough Kay; the "Castle of the Rock," he indicates, he was originally inspired to do this. This romantically isolated castle which is permeated with reminders of Irish mythology and folklore suggested to Yeats "a retreat for a mystical order which would be served by the allied power of literature and national consciousness." Members of this Mystical Order would have the opportunity to meditate and read books on "Irish art, history, and myth," ...philosophy and the occult (ibid. 74). Yeats philosophical quest for order was culminated in $a$ Vision which he published in 1926 in an edition of 600 copies. After his marriage in 1917, Yeats and George, his wife, experimented with several variations recorded in "sleeps." George Mills Harper and Walter Kelly Hood, the editors of Yeats's A Vision, in their "Editorial Introduction" to the book, prepared a table of séances (meetings to communicate with spirits through a medium) that lasted from October 4, 1917, to March 21, 1924. The total number of séances was 450 , the number of questions was 8672 , and the total number of pages of notebooks that recorded these sessions was 3627 pages. The total number of sessions of sleep and meditations 
was 164; the pages preserved were 270 pages (Harper and Hood, p. xix-xxi). These notebooks were what Yeats called Automatic Script. In this incredible experience, Yeats tries to classify or categorize human beings according to the 28 phases or "the Arabian 28 mansions" of the moon to give his own view of history as a series of gyres which are spiral paths traced out on cones, where each age is seen as the antithesis of the previous one.

The book, as Yeats indicates, was the result of long hours of mediumship, telepathy, and automatic writing. What matters here is Yeats's use of the book in his later poetry, especially the doctrine of the gyres, which recurs in many of his poems, especially "Sailing to Byzantium." The gyre, the dance, the dancers, the moon, the sun, the soul, and the body, the mask, the bird and the tree are recurrent symbols in A Vision. However, though Yeats drew a lot of ideas, metaphors, and symbols from his A Vision, it remains an absolutely obscure book, difficult to digest for readers and even for critics of Yeats; but it remains, also, the most important work for anyone who wants to understand his art and thought, because A Vision "gave Yeats," to use Unterecker's words, "a philosophical framework on which he could hang such poems as "Phases of the Moon," "Shepherd and Goatherd," the Byzantium poems and "All Souls' Night" (Unterecker, 1959, p. 29).

"The Wheel and the Phases of the Moon" which Yeats included at the opening of Book I of his A Vision, introduces his two fictional characters Owen Aherne and Michael Robartes as the fantastic friends who delivered the manuscript of A Vision to him; they talk about Yeats as a "Shelleyan visionary" seeking what he shall never find: An image of mysterious wisdom won by toil, and now he seeks in book or manuscript What he shall never find (Yeats: A Vision 183). This implies that the order Yeats is looking for unattainable. In "The Lake Isle of Innisfree," the poet dreams of escape to the idyllic world of the island and to the simple life. The poem was written in London in 1890. Yeats, influenced by Thoreau's Walden, dreamed of living alone in search of wisdom" (Jeffares, 1974, p. 209) though the poem is an autobiographical one recording an actual experience in the poet's life when he was standing "very homesick... before a shop window that displays a little fountain. He said"I ... began to remember lake water. From the sudden resemblance came my poem "Innisfree" (Unterecker, 1959, p. 80). "The Second Coming," one of Yeats's finest poems that tackle his ideas of A Vision, was inspired by disorder and the anarchy of the world; the world of bloodshed, disbelief, and despair, the poem is a vision; an insight into the future. To use Yeats image of the interlocking cones, the present era - at the top of the cone - is dying. The poem embodies Yeats's theory of history which was developed in A Vision that a period of anarchy and disorder is to be followed by a period of order, faith, innocence, and peace. This poem is closely related to "The Phases of the Moon" as far as the belief in Magnus Annus: The Great Year is concerned. Yeats believes that every 2000 years, a great year of death and rebirth will be brought and "this belief with respect to individuals seems to be associated with the phases of the moon." Furthermore, these beliefs "have a scaffold of geometrical figures, gyres, cones, circles, etc., by the application of which exact interpretation is secured" (Blackmur, p. 119). Thus, it is possible to predict in biography and history, forward and backward the collapse and rebirth of human types and cultures. In the "Introduction" to "The Resurrections," Yeats describes the image used in this poem which he had seen many times "always at my left side just out of the range of sight, a brazen winged beast that I associated with laughing ecstatic destruction" (qtd. in Blackmur, p. 117). Ecstasy, argues Blackmur, "comes for Yeats before death, and at death comes the moment of revelation when the soul is shown its kindred dead, and it is possible to see the future" (ibid., p. 117-118). The images, therefore, are traced in Yeats's mind to sources of supernatural character and to the Spiritus Mundi, which is a term adapted from Henry Moore's anima mundi: Animating spirit (Wollman, p. 207-208). For Yeats, Spiritus Mundi means the collective memory or the collective subconscious, "a general storehouse of images which have ceased to be a property of any possibility;" these images have an operative force in "predicting events in the world" (Blackmur, p. 118).

"The Second Coming," therefore, looks at the Christian era as being at its end where the gyre is sweeping outward to reach its greatest expansion symbolizing a state of anarchy and disorder that

Things fall apart; the center cannot hold;

More anarchy is loosed on the world

The blood-dimmed tide is loosed, and everywhere

The ceremony of innocence is drowned (CP 211).

The gyre had reached its limit, therefore, this era is due for replacement: "When, however," Yeats says in A Vision, "a narrowing and a widening gyre reach their limit, the one the utmost contraction, the other the utmost expansion they change places, point to circle, circle to point" (A Vision 131). The second coming of Christ, therefore, is at hand:

Surely some revelation is at hand,

Surely the Second Coming is at hand. (CP 211)

However, hardly does he say these words when a vast fearful image troubles his sight. His vision turns into a nightmare:

When a vast image of Spiritus Mundi Troubles my sight: Somewhere in sands of the desert 
A shape with lion body and the head of a man,

A gaze blank and pitiless as the sun

Is moving its slow thighs....

This hope in the second coming of Christ is marred by the coming of the beast.

"Leda and the Swan" (1923) is another symbolic poem on the intellectual, impersonal order. This poem is about the rape of Leda by Zeus disguised as a swan; a rape which led to the birth of Helen of Troy, the destruction of Troy, and the disintegration of early Greek civilization. Like "The Second Coming" it deals with violence and with the cycles of history, where every cycle begins and ends with violence. Book III of $A$ Vision: "Dove or Swan," opens with the poem "Leda and the Swan," then it is followed by his argument about the great wheel and history where he comments on this poem:

I imagine the annunciation that founded Greece as made to Leda, remembering that they showed in a Spartan Temple, strung up to the roof as a holy relic, an unhatched egg of hers, and that from one of her eggs came love and from the other war. But all things are from antithesis, and when in my ignorance I try to imagine what older civilization she refuted I can but see birds and women blotting out some corner of the Babylonian mathematical starlight. (A Vision 181).

This annunciation in that of the rape of Leda by Zeus is paralleled to the annunciation to Mary - the account of the rape is given in the first eight lines of the sonnet:

A sudden blow, the great wings beating still Above the staggering girl, her thighs caressed

By the dark webs, her nape caught in his bill,

He holds her helpless breast on breast. (CP 241)

Blackmur believes that the poem can be read on at least three distinct levels: "The level of dramatic fiction, of condensed insight into Greek mythology, and the third level of fiction and insight" (Blackmur, p. 134).

In the first part of the sestet, the poem says that the swan has engendered the fall of troy and the death of Agamemnon. The difficulties of the poem, says Yvor Winters, reside in the last portion of the sestet; in the unanswered question:

Did she put on his knowledge with his power Before the indifferent beak could let her drop?

And he unconvincingly argues that though she was "overpowered or raped" but "she did put on his power" through the implied "mystical union of the sexual act" (Winters, p. 266). Power and knowledge are two antithetical forces; they could never exist together in the world. As far as 1896, says Ellmann, Yeats had used this myth in "The Adoration of the Magi" where he had prophesied that another Leda would be raped by the "swan" to begin a new age. The poet's question at the end of the sonnet is whether the copulation has resolved the "antinomy of knowledge against power" (Ellmann, p. 244-246).

As for Yeats's quest for a mystical order, with George Russell, Charles Jonston, Claude Wright, and Charles Weekes he began to study mysticism, Eastern religions, and European magic and they founded the Dublin Hermetic Society which met for the 1st time in June 16, 1885, to discuss, as Yeats announced, the wonders of Eastern philosophy (ibid. 42). The other movement he joined was the Blavatsky Lodge, founded by the strange Russian lady, Madame Blavatsky - originally it was called "Theosophy." Yeats joined the Lodge in May 1887. Through Madame Blavatsky and her Lodge, he came into contact for the first time with cosmology and then with the occult. According to her "doctrine," the world is a conflict of opposites, such as good and evil. This, with her other theosophical views and spiritual doctrines were of great interest for Yeats (ibid. 58-65).

On March 7, 1890, Yeats joined the Hermetic Students of the Golden Dawn, which was founded in 1888, with similar suppositions about God, the universe, and man. In this society, the occult rituals were emphasized. In the Golden Dawn, Yeats learned to fix his mind upon the images he seeks to evoke, with intensity previously unknown to him (ibid. 89-91).

Through his interest in the occult, Yeats hoped that he "could discover the design of the world of spirit" and hence, the world of matter would make sense. The occult "offered systems of order" (Unterecker, 1963, p. 23), which brought the two worlds (of the spirit and of the matter) close to each other.

However, "The Lake Isle of Innisfree" becomes one of his most popular poems. Yeats himself said that "'Innisfree' was his finest properly Irish poem" (MacNeice, p. 56). Though the poem is considered an escapist one by MacNeice, the escape here is an escape to a real place in Ireland, a place where Yeats had spent a considerable part of his childhood. His dissatisfaction with the world of London and with "the pavements gray" and his nostalgic dreams were behind his identification of himself, in the opening lines of the first and third stanzas, with the Prodigal son (Luke: xv, 18):

I will arise and go now, and go to Innisfree,

And a small cabin build there, of clay and wattles made: Nine bean-rows will I have there, a hive for the honey-bee, And live alone in the bee-loud glade. (CP 44).

It is the first poem in which he expressed his desire for a solitary mystical life in an ideal island. This is reminiscent of Aengus, "the god of poetry" who, like the poet of "Innisfree" lives "in a house made of wattles, clay, and skin in much the way that Yeats had hoped to live in his own ideal island, Innisfree" (Unterecker, 1959, p. 52). The image of the island as a retreat from the 
disordered world to a land of peace, love, and mystical order recurs in many of Yeats's lyrics such as "To an Isle in the Water" and "The Stolen Child." In "To an Island in the Water," the poet is ready to go to the isle:

To an isle in the water

With her would I go. (CP 22)

"The Stolen Child" is also set in a place in Sligo. This time the flight takes place into a fairyland, where "the child" is invited by the fairies to

Come away, O human child!

To the waters and the wild

With a faery, hand in hand

For the world's more full of weeping than you can understand. (CP 20

The power of the fairies was particularly strong there and the child had yet to make some sacrifices in his journey to the land of the fairy; everyday, comfortable spirits and sounds had to be abandoned for new and carefree land.

Yeats's dream of a mystical order, however, cannot be achieved. Reading "Innisfree," one feels that the poet realizes that his dream of the mystical order is unattainable, and to use Garrett's words, "that Innisfree will remain forever out of reach" (Garrett, 205) because in spite of his decision to "arise and go now" in the opening lines of the first and third stanzas "yet his feet remain firmly planted where they are... stubbornly refusing fancy" (ibid., 205). Like any mystic who frees himself from the bonds of flesh and from the materialistic world, his enthusiasm to free himself from the disorders of the world; from the "pavements gray" of the city to found a self-sufficient earthly paradise falls short, for he only hears the "lake water" whereas he is standing still:

I hear lake water lapping with low sounds by the shore; While I stand on the roadway, or on the pavements gray, I hear it in the deep heart's core. (CP 44)

In his quest for order, Yeats's mind is turned this time to Byzantium. Yeats "interest is Byzantine art and civilization began in the 90s and continued through his life" (Bradford, p. 93). Furthermore, Byzantium was germinating in Yeats mind from an early date "as an analog to Gaelic Ireland, both being representative of a unified culture where all great modern divisions are almost completely unknown" (McAlindon, p. 31). McAlindon emphasizes the "profound and lasting" influence of William Morris's lectures, pamphlets, and essays "on the arts and crafts and their history" during the 1880s in which Byzantium was "a constant preoccupation" (ibid., 307). Yeats never saw Byzantium "(except in photographs, and probably, in Fossati's famous lithographs) with its "supernatural splendor" its "golden ground," its walls of "little glimmering cubes of blue and green and gold" (ibid., 314). This golden world of Byzantium is to be reflected in the golden images of the tree and the bird in Yeats's poem.

In "Sailing to Byzantium" the poet expresses his determination, now he becomes old, to leave the sensual world and to turn to the world of the spirit.

This is no country for old men. The young

In one another's arms, birds in the trees

- Those dying generations - at their song

The salmon-falls, the mackerel-crowded seas,

Fish, flesh, or fowl, commend all summer long

Whatever is begotten, born, and dies.

Caught in that sensual music all neglect

Monuments of unaging intellect (CP 217).

Old age, the old man in the poem says, excludes a man from the sensual world of the young generations. The city, which he decides to leave completely belongs to the young because the old man is just "a tattered coat upon a stick;" a scare crew. This country of the young in its water "fish," on its earth "flesh" and in its air "foul," is completely given over to sensuality. They commend "all summer long" mortal things, and their commendation, therefore, lasts for a very short time only. Because they are caught in sensuality, the young neglect anything connected with the spirit "Monuments of spiritual things" (Olson 215-230).

An old man, the poet says in the second stanza, is worse than the young, unless the soul can grow stronger as the body ages and dies "Unless/Souls clap its hands and sing, and louder sing." "In Book III of A Vision, Yeats writes"

In our system also it is a cardinal principle that everything separated from its opposite - any victory is a separation "consume itself away." The existence of one depends on the existence of the other (A Vision 134).

The soul of the old man can only rejoice (learn singing) by studying "Monuments" that are neglected by the young and that is why the poet decides to sail the seas to "the holy city of Byzantium"

In the third stanza, the old man prays to the sages in the holy fire of the wall mosaic to

Come from the holy fire, perne in a gyre, and be the singing-masters of my soul -

The "gyre" recurs in many of Yeats poems because this spiral movement is associated with religious dance and with the ascension of the spirit. Again, in A Vision, he says "I remember that certain Irish countrymen whom I questioned once 20 years ago had seen Spirits departing from them in an ascending gyre" (A Vision 128). Then, he asks the sages to "consume" his "heart away, sick with desire," because the soul "cannot grow into likeness with these beings of immortal embodiment unless it cast off its mortal body utterly" (Olson, p. 223- 
224). The word "consume," Harper and Hood argue, is one of the favorite words for Yeats:

It appears several times in the AS [Automatic Script] and in poems written during this time and later. A sentence in a rejected type-script clarifies Yeats meaning; thought dies when tension dies fading and through a process of abstraction - "all things separate from their opposite consume themselves away'" (Harper and Hood "Notes" to A Vision 34).

Once out of his animal body, his soul will be free to choose some new embodiment, but it will never again choose the human body which ages so quickly; it will choose

...such a form as Grecian goldsmiths made Of

hammered gold and gold enameling To keep a

drowsy Emperor awake;

The soul, therefore, will choose art: The golden bird which is "set on a golden bough to sing;" which is immortal and incorruptible unlike the mortal "birds in the trees" of Stanza One. The poem, therefore, deals with the poet's dream voyage to eternity, his dream of a golden city of art. He makes his soul set sails for the center of European civilization; a city where the spiritual life and the creation of art merge as one, and where the unity of being and unity of culture can be achieved.

\section{CONCLUSION}

In his quest for order and in his later poetry, Yeats grew more and more realistic as a result of his hopelessness to attain the romantic Utopia of the legendary past. As he grew older he began to realize that it was impossible to attain his dream. He realized that bringing himself, his country and his literature back to the old order of things; to the "unity of culture" of the Middle Ages - was hopeless. He felt that though Irish freedom was partly achieved, but the glorious great houses were destroyed. His dreams of a mystical order in Innisfree or in a "unity of culture" through reviving Irish legendary and folk literature, or in Byzantium or even his philosophical order in his A Vision, all came to nothing. There is the feeling, therefore, that in his old age, and in his later poetry there is a great change in his thinking and in his poetry.

\section{REFERENCES}

Blackmur, R.P. (1979) In: William, H. Pritchard., (eds.), The later poetry of W. B. Yeats: A critical anthology. London: Penguin Books.

Bradford, C. (1963) In: John, U., (ed.), Yeats's byzantium poems: A study of their development Yeats: A collection of critical essays. New Jersey: Prentice Hall Inc.

Edward, A. (1979) W. B. Yeats: The poems. Southampton: The Camelot Press, LTD
Ellmann, R. (1966) Yeats: The man and the mask. London: Faber and Faber.

Garrett, J. (1986) British poetry since the sixteenth century: A student's guide. London: Macmillan.

Harper, G.M. and Walter, K.H. (1978) Introduction to a critical edition of yeats's a vision. London: The Macmillan Press LTD.

Jeffares, N., (ed.) (1974) Introduction to W. B. Yeats: Selected poetry. London: Pan Books.

Unterecker, J. (1959) A reader's guide to William butler yeats. New York: Octagon Books.

MacNeice, L. (1967) The poetry of W. B. Yeats. London: Faber and Faber.

McAlindon, T. (1967) The idea of Byzantium in William Morris and W. B. Yeats Modern Philology, 64(4), pp. 311-318.

Olson, E. (1962) Sailing to byzantium': Prolegomena to a poetics of the lyric. In: Wilbur, S., (ed.), Five approaches to literary criticism. New York: Macmillan Publishing Company.

Pritchard, W.H. (1972) W. B. Yeats: A critical anthology. London: Penguin Books.

Ronsley, J. (1968) Yeats's autobigraphy: Life as symbolic pattern. Cambridge: Harvard University Press.

Scott, W.S., (ed.) (1962) Five approaches to literary criticism: An arrangement of contemporary critical essays. New York: Collier Books.

Spencer, T. (1972) In: William P., (ed.). The tower W. B. Yeats: A critical anthology. London: Penguin Books.

Strandberg, V. (1964) The crisis of belief in modern literature. The English Journal, 53(7), pp. 481-483.

Unterecker, J., editor. (1963) Yeats: A Collection of Critical Essays. NJ: Prentice Hall.

Willman, M., (ed.) (1972) Ten twentieth-century poets. London: Harrap.

Wilson, J.B. (1972) English Literature: A Survey for Students. London and Harlow: Longmans, Green and Co. Ltd.

Winters, Y. (1972) Pritchard, W.A., editor. From Forms of Discovery.

W. B. Yeats: A Critical Anthology. London: Penguin Books.

Yeats, W,B. (1966). Autobiographies. London: Macmillan

Yeats, W.B. (1958) The collected poems of W. B. Yeats. London: Macmillan and Co. Ltd.

Yeats, W.B. (1978) George, M.H. and Water, K.H., editors. A critical edition of Yeats's a vision (1925). London: The Macmillan Pess LTD. 